\title{
Early diagnosis of porphyria cutanea tarda as a key to avoiding scarring - a mild form of the disease
}

\section{Wczesne rozpoznanie porfirii skórnej późnej jako kluczowy element zapobiegania bliznowaceniu - łagodna postać choroby}

\author{
Marcela A. Nowak, Dorota Mehrholz, Wioletta Barańska-Rybak, Roman J. Nowicki \\ Department of Dermatology, Venereology and Allergology, Medical University of Gdańsk, Poland \\ Katedra i Klinika Dermatologii, Wenerologii i Alergologii, Gdański Uniwersytet Medyczny, Polska
}

Dermatol Rev/Przegl Dermatol 2019, 106, 515-521 DOI: https://doi.org/| 0.5। |4/dr.2019.89999

\section{CORRESPONDING AUTHOR/ ADRES DO KORESPONDENCJI: Marcela A. Nowak \\ Katedra i Klinika Dermatologii, Wenerologii i Alergologii Gdański Uniwersytet Medyczny ul. Marii Skłodowskiej-Curie 3 80-001 Gdańsk, Polska tel.: +48606908780 e-mail: mcela94@gmail.com}

\begin{abstract}
Porphyria cutanea tarda belongs to the group of porphyrias. Porphyria is a heme disorder caused by an acquired or congenital defect of hepatic enzymes. This consequently leads to the accumulation of porphyrins in various organs. In porphyria cutanea tarda, there is a deficiency of the enzyme uroporphyrinogen decarboxylase. The most frequent factor that leads to damage of this enzyme is drug- or alcohol-induced liver insufficiency. In porphyria cutanea tarda typical clinical manifestations include blisters, erosions, crusts, and milia, that arise predominantly in sun-exposed areas. Furthermore, the skin becomes atrophic, susceptible to injuries and scarring. In our patient, the skin chances were induced by estrogen treatment of endometriosis in combination with UV-exposure. In this case the diagnosisi was established early and significant clinical consequences could be avoided.
\end{abstract}

\section{STRESZCZENIE}

Porfiria skórna późna jest chorobą należącą do grupy porfirii. Istotą porfirii są zaburzenia syntezy hemu spowodowane nabytym lub wrodzonym upośledzeniem aktywności enzymów wątrobowych. Choroba skutkuje nadmiernym gromadzeniem się porfiryn w różnych narządach organizmu. U chorych z porfirią skórną późną obserwuje się niedobór enzymu dekarboksylazy uroporfirynogenu. Najczęstszym czynnikiem prowadzącym do upośledzenia funkcji tego enzymu jest niewydolność wątroby będąca skutkiem działania niektórych leków lub alkoholu. Charakterystyczne wykwity skórne w przebiegu porfirii skórnej późnej obejmują pęcherze, nadżerki, strupy i prosaki, które powstają głównie w lokalizacjach eksponowanych na promieniowanie UV. Ponadto skóra staje się atroficzna, podatna na urazy i bliznowacenie. Przedstawiamy pacjentkę, u której czynnikiem indukującym chorobę było leczenie endometriozy estrogenami oraz ekspozycja na działanie promieniowania UV. $\mathrm{W}$ opisanym przypadku wczesne rozpoznanie pozwoliło na uniknięcie powikłań choroby.

Key words: porphyria cutanea tarda, porphyria, hormonal replacement therapy.

Słowa kluczowe: porfiria skórna późna, porfiria, hormonalna terapia zastępcza. 


\section{INTRODUCTION}

Porphyria cutanea tarda (PCT) belongs to a group of diseases in which the function of liver enzymes in the heme synthesis pathway is impaired. There are two types of the disease - the first one is acquired and the other shows autosomically dominant inheritance [1]. In this type of porphyria there is a deficiency of the enzyme uroporphyrinogen decarboxylase [2]. The most frequent cause of damage to this enzyme is liver failure, chronic alcoholism and usage of exogenous estrogens [3]. Smoking can also induce cytochrome P1A2, and therefore cause porphyria by producing a recently discovered uroporphyrinogen decarboxylase inhibitor [4]. Other factors include drugs such as barbiturates, hydantoins, other antiepileptic drugs, and sulfonamide antibiotics (table 1). Attacks usually occur within 24 hours after exposure to a precipitating drug. Therefore, if possible, administration of those drugs should be avoided. Furthermore, autoimmune diseases and some viral infections such as HCV are also associated with PCT [5]. Porphyria cutanea tarda is the most common type of porphyria worldwide. It has an estimated prevalence of $1: 10000$.

In the course of this disease, porphyrins are formed, accumulate in the skin and are excreted with the urine. Skin changes are caused by the breakdown of porphyrins in the skin under the influence of UV light. Clinical symptoms include non-inflammatory blisters, often coexisting with bleeding and scarring, erosions, pustules and crusts [6]. The first symptoms occur between 40 and 70 years of age. Chronic damage to the skin can manifest itself in changes in pigmentation. Moreover, the skin becomes thinner, making it more susceptible to injuries and scarring. Other symptoms may include joint pain in the upper and lower extremities, dizziness, tinnitus and abdominal pain [7].

The most common skin lesions in alcohol addicts include jaundice, pruritus, hyperpigmentation, telangiectasias, capillary hemangiomas, caput medusae and palm erythema [8].

In the group of patients with familial PCT, the genetic decrease in uroporphyrinogen decarboxylation increases the sensitivity to the toxic effects of iron [9]. The simplest treatment for iron overload in nonuremic patients is removal of iron by venesection [10]. However, in patients in whom venesection is not feasible, the chelating agent deferoxamine or one of the newer oral iron chelators such as deferasirox, can effectively remove excess iron [11]. This method is useful when iron overload is associated with anemia and in patients on hemodialysis.

\section{WPROWADZENIE}

Porfiria skórna późna (porphyria cutanea tarda - PCT) należy do grupy chorób wywoływanych zaburzeniem działania enzymów wątrobowych w szlaku syntezy hemu. Wyróżnia się dwa typy choroby: nabyty oraz o podłożu genetycznym, dziedziczony w sposób autosomalny dominujący [1]. W porfirii skórnej późnej występuje niedobór enzymu dekarboksylazy uroporfirynogenu [2]. Do najczęstszych przyczyn upośledzenia funkcji enzymu należą: niewydolność wątroby, przewlekła choroba alkoholowa oraz stosowanie egzogennych estrogenów [3]. Palenie tytoniu może indukować cytochrom P1A2, wywołując porfirię poprzez wpływ na syntezę niedawno odkrytego inhibitora dekarboksylazy uroporfirynogenu [4]. Inne czynniki wyzwalające porfirię to leki, m.in. barbiturany, hydantoiny, inne leki przeciwpadaczkowe oraz antybiotyki sulfonamidowe (tab. 1). Choroba rozwija się zazwyczaj w czasie 24 godzin od narażenia na działanie leku indukującego chorobę. Z tego względu należy unikać stosowania tych leków. Stwierdza się ponadto zależność między PCT a chorobami autoimmunologicznymi i zakażeniem niektórymi wirusami, np. HCV [5]. Porfiria skórna późna jest najpowszechniejszym typem porfirii na świecie. Częstość występowania choroby szacuje się na $1: 10000$ osób.

W przebiegu choroby dochodzi do wytwarzania porfiryn, które gromadzą się w skórze i są wydalane $\mathrm{z}$ moczem. Zmiany skórne są wywoływane rozpadem porfiryn w skórze pod wpływem promieniowania UV. Obraz kliniczny obejmuje niezapalne pęcherze, którym często towarzyszy krwawienie i bliznowacenie, a także nadżerki, krostki i strupy [6]. Pierwsze objawy występują między 40. a 70. rokiem życia. Przewlekłe uszkodzenie skóry może objawiać się zaburzeniami barwnikowymi. Skóra staje się ścieńczała, przez to bardziej podatna na urazy i bliznowacenie. Do innych objawów zalicza się: ból stawów kończyn górnych i dolnych, zawroty głowy oraz ból brzucha [7].

Do najczęstszych zmian skórnych u osób uzależnionych od alkoholu należą: zażółcenie skóry, świąd, przebarwienia, teleangiektazje, naczyniaki krwionośne włośniczkowe, „głowa meduzy” i rumień powierzchni dłoniowej rąk [8].

U pacjentów z rodzinnym typem PCT genetyczne ograniczenie dekarboksylacji uroporfirynogenu nasila wrażliwość na toksyczne działanie żelaza [9]. Najprostszym sposobem leczenia przeciążenia żelazem $u$ chorych bez mocznicy jest jego usunięcie poprzez upusty krwi [10]. U pacjentów, u których nie można wykonać tego zabiegu, skuteczną metodą usunięcia nadmiaru żelaza jest zastosowanie leku chelatującego - deferoksaminy - lub jednego z nowszych doustnych środków chelatujących żelazo, takich jak deferazyroks [11]. Ta metoda jest przydatna, gdy przeciążenie żelazem ma związek z niedokrwistością oraz u pacjentów poddawanych hemodializom. 
Table I. Factors that aggravate the symptoms of PCT and/or are lethal in patients with PCT

Tabela I. Czynniki, które nasilają objawy PCT i/lub odpowiadają za śmiertelny przebieg choroby

\begin{tabular}{|c|c|}
\hline $\begin{array}{l}\text { Excess alcohol consumption/ } \\
\text { Spożywanie nadmiernych ilości alkoholu }\end{array}$ & $\begin{array}{l}\text { Estrogen based hormonal replacement therapy/ } \\
\text { Hormonalna terapia zastępcza oparta na estrogenach }\end{array}$ \\
\hline Smoking/Palenie tytoniu & $\begin{array}{l}\text { Analgesic (diclofenac, dextropropoxyphene, meprobamate, } \\
\text { propoxyphene, tramadol)/Leki przeciwbólowe (diklofenak, } \\
\text { dekstropropoksyfen, meprobamat, propoksyfen, tramadol) }\end{array}$ \\
\hline Excess iron intake/Nadmierna podaż żelaza & $\begin{array}{l}\text { Anticonvulsant (barbiturates, carbamazepine, diones, } \\
\text { lamotrigine, phenytoin, primidone, valproate)/Leki } \\
\text { przeciwdrgawkowe (barbiturany, karbamazepina, diony, } \\
\text { lamotrygina, fenytoina, prymidon, walproinian) }\end{array}$ \\
\hline $\begin{array}{l}\text { Estrogen-containing oral contraceptive pills/Doustne leki } \\
\text { antykoncepcyjne zawierające estrogen }\end{array}$ & $\begin{array}{l}\text { Local anesthetic (lidocaine)/Miejscowe środki znieczulające } \\
\text { (lidokaina) }\end{array}$ \\
\hline $\begin{array}{l}\text { Drugs for cardiovascular disorders (dihydralazine, hydralazine, } \\
\text { lidocaine, methyldopa, nifedipine, spironolactone)/Leki stosowane } \\
\text { w zaburzeniach sercowo-naczyniowych (dihydralazyna, } \\
\text { hydralazyna, lidokaina, metylodopa, nifedypina, spironolakton) }\end{array}$ & $\begin{array}{l}\text { Anxiolytics (hydroxyzine, glutethimide)/Leki przeciwlękowe } \\
\text { (hydroksyzyna, glutetimid) }\end{array}$ \\
\hline $\begin{array}{l}\text { Anti-infective (chloramphenicol, clindamycin, erythromycin, } \\
\text { indinavir, ketoconazole, nitrofurantoin, rifampin, ritonavir, } \\
\text { sulfonamides, trimethoprim)/Leki przeciwinfekcyjne } \\
\text { (chloramfenikol, klindamycyna, erytromycyna, indynawir, } \\
\text { ketokonazol, nitrofurantoina, ryfampina, rytonawir, sulfonamidy, } \\
\text { trimetoprim) }\end{array}$ & $\begin{array}{l}\text { Antihyperglycemic (sulfonylureas)/Leki hipoglikemizujące } \\
\text { (pochodne sulfonylomocznika) }\end{array}$ \\
\hline
\end{tabular}

\section{CASE REPORT}

A woman, 34 years old, was admitted to the dermatology clinic for further diagnosis of blister-erosive lesions located on the dorsal surface of the hands (figs. 1).

The first skin lesions appeared after exposure to ultraviolet radiation, in August 2017. Most of the lesions consisted of tense blisters on the unchanged skin on the dorsal surface of the hands. Initially, the lesions were treated as contact dermatitis, treated with local glucocorticosteroids, without improvement. Then the patient was diagnosed with suspected lupus erythematosus with the following results: ANA Hep2 $1: 2560$, histone + . The patient did not manifest Raynaud's symptom, but often had cold hands and burning sensations after exposure to cold. Methylprednisolone $12 \mathrm{mg}$ was prescribed in October and November with a gradual dose reduction. Then the skin lesions, the feeling of cold hands, joint discomfort, abdominal pain and tiredness disappeared. The lupus band test (LBT) carried out on $9^{\text {th }}$ November 2017 revealed deposits of IgA, IgM, and IgG, complement components $\mathrm{C} 3 \mathrm{c}, \mathrm{C} 1 \mathrm{q}$ in the wall of superficial skin vessels and fibrous IgM deposits that lay parallel to the skin-epidermal border.

Moreover, the patient reported pathological fatigue, pain and increased muscle tone (nervous conduct was normal), pain in the joints (rheumatoid factor and anti-citrullinated protein antibodies were negative), dry eyes and mouth, and abdominal colic pains several times a month. Gastroscopy was conducted, and revealed antrum inflammation.

\section{OPIS PRZYPADKU}

Kobieta 34-letnia została przyjęta do kliniki dermatologicznej w celu dalszej diagnostyki zmian pęcherzowo-nadżerkowych zlokalizowanych na grzbietowej powierzchni rąk (ryc. 1).

Pierwsze zmiany pojawiły się po ekspozycji skóry na promieniowanie ultrafioletowe w sierpniu 2017 roku. Większość wykwitów miała postać napiętych pęcherzy umiejscowionych na niezmienionej skórze powierzchni grzbietowej rąk. Początkowo ustalono rozpoznanie kontaktowego zapalenia skóry. Zastosowano miejscowe leczenie glikokortykosteroidami, jednak nie uzyskano poprawy. Następnie pacjentkę diagnozowano w kierunku tocznia rumieniowatego i uzyskano następujące wyniki badań: ANA Hep2 $1: 2560$, histon + . Kobieta nie obserwowała objawu Raynauda, ale zgłosiła, że często ma zimne ręce i odczuwa pieczenie po ekspozycji skóry na niskie temperatury. W październiku i listopadzie do leczenia wprowadzono metyloprednizolon w dawce $12 \mathrm{mg}$, którą stopniowo zmniejszano. Stwierdzono ustąpienie zmian skórnych, uczucia zimnych rąk, dyskomfortu w stawach, bólu brzucha oraz zmęczenia. Badanie LBT (lupus band test) wykonane 9 listopada 2017 roku wykazało obecność złogów IgA, IgM i IgG, składowych dopełniacza C3c i C1q w ścianie powierzchownych naczyń skórnych oraz homogennych złogów IgM w strefie błony podstawnej.

Pacjentka zgłaszała ponadto nasilone zmęczenie, bóle mięśni ze wzmożonym napięciem mięśniowym (przewodnictwo nerwowe było prawidłowe), ból stawów (czynnik reumatoidalny i przeciw- 

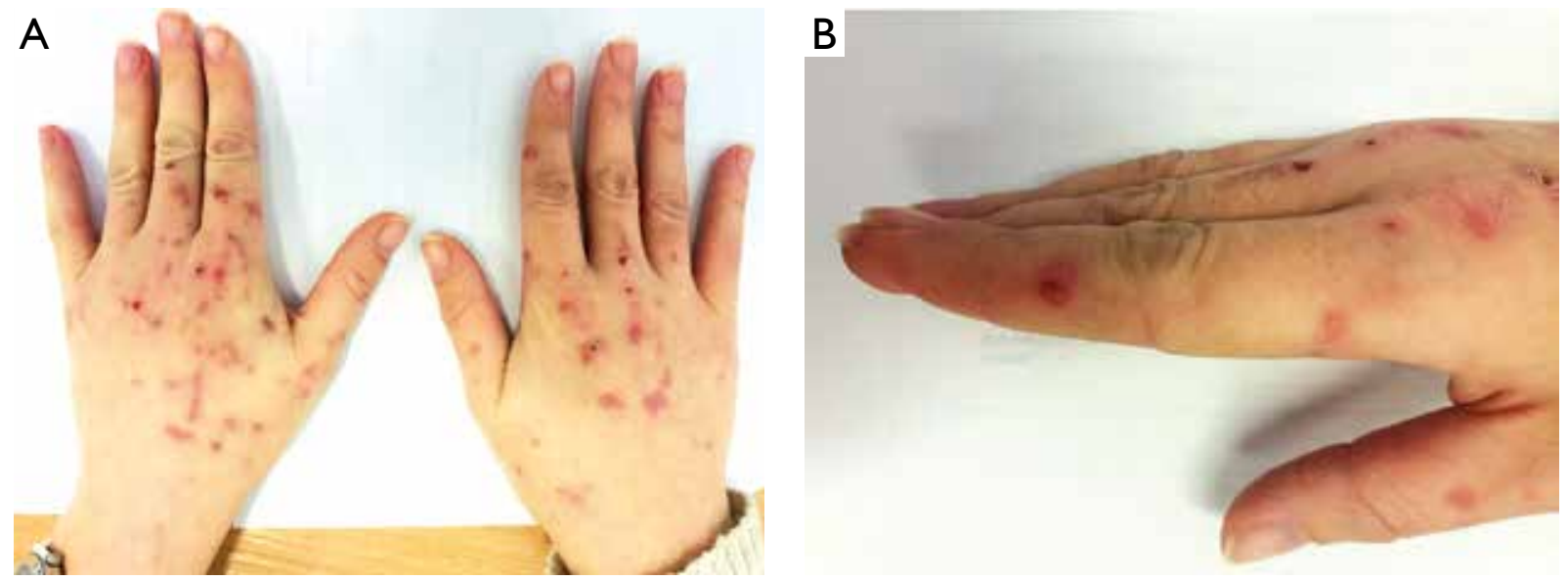

Figure I. A, B - Skin lesions (blisters, erosions, crusts) of our patient which are present at the beginning of therapy in the clinic Rycina I. A, B - Zmiany skórne (pęcherze, nadżerki, strupy) u pacjentki na początku leczenia w Klinice

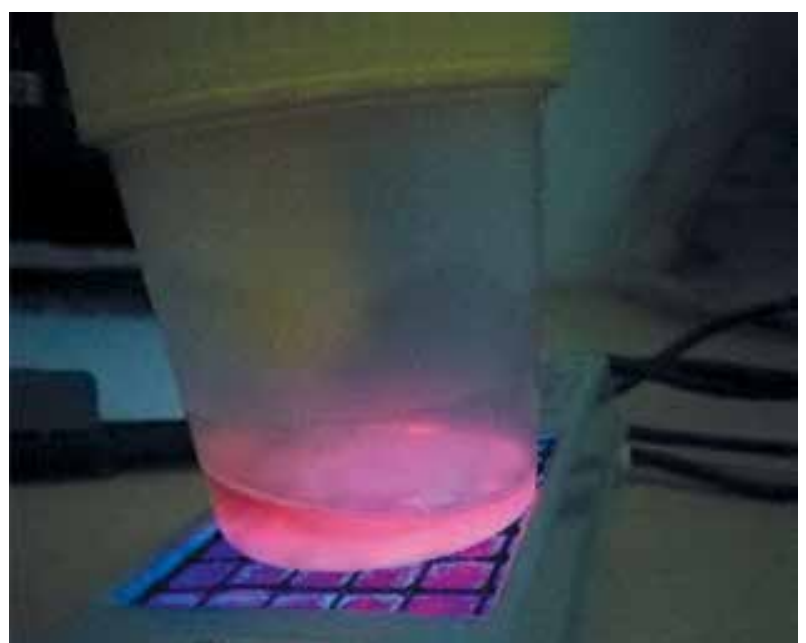

Figure 2. Urine glowing pink in the Wood lamp

Rycina 2. Różowe zabarwienie moczu w świetle lampy Wooda

Pantoprazole $40 \mathrm{mg}$ was implemented. Due to the persistently elevated MCV (106 fl), the diagnosis of Addison-Birmer disease was made. The anti-parietal cell antibodies were negative. The patient was additionally burdened with: Hashimoto's disease (in 2012 - ft3 $4.79 \mathrm{pmol} / \mathrm{dl}$, ft4 $16.82 \mathrm{pmol} / \mathrm{dl}$ anti-Tg $35.89 \mu \mathrm{l}$, anti-TPO $36.93 \mu \mathrm{l}$, TSH $5.28 \mathrm{mIU} / 1$ and increased flow in the thyroid parenchyma as seen in ultrasound scan), endometriosis lasting many years, treated with a combination of ethylene estradiol $0.03 \mathrm{mg} /$ day and dienogestene $2 \mathrm{mg} /$ day. Fallopian tubes were occluded, with post-inflammatory changes. The patient was in the preparatory period for an in vitro fertilization procedure, after 3 injections of gonadoliberin. The patient had undergone a double ovarian cyst treatment and peritonitis in 2000, 3 weeks after which another operation was performed due to endometriosis. Hepatistis C and B virus, and HIV infections were ruled out. ciała przeciwko cyklicznemu cytrulinowanemu peptydowi były ujemne), suchość oczu i jamy ustnej oraz kolkowe bóle brzucha kilka razy w miesiącu. Wykonano gastroskopię, która wykazała zapalenie antrum. Do leczenia włączono pantoprazol w dawce $40 \mathrm{mg}$. Z powodu utrzymującego się podwyższonego MCV (106 fl) rozważano rozpoznanie choroby Addisona-Biermera. Badanie przeciwciał przeciwko komórkom okładzinowym dało wynik ujemny. Wśród innych obciążeń u pacjentki stwierdzono: chorobę Hashimoto (w 2012 roku: ft3 4,79 pmol/dl; ft4 16,82 pmol/dl; anty-Tg 35,89 $\mu \mathrm{l}$; anty-TPO 36,93 $\mu \mathrm{l}$; TSH 5,28 mIU/1 i wzmożony przepływ w miąższu tarczycy wykazany w badaniu ultrasonograficznym) oraz wieloletnią endometriozę leczoną etylenem estradiolu w dawce $0,03 \mathrm{mg} /$ dobę w skojarzeniu z dienogestenem w dawce $2 \mathrm{mg} /$ dobę. Jajowody były niedrożne, z widocznymi zmianami pozapalnymi. Pacjentka była w okresie przy- 
Due to a significant tendency to hand skin injuries, the fact that blisters were exacerbated by UV radiation and dark brown urine was reported by the patient and a typical LBT test result, PCT was suspected.

During the hospitalization, the patient was referred to undergo tests for porphyria. The results were as follows: the level of protoporphyrin and the coproporphyrin increased to $270 \mu \mathrm{g}$ in 24 hours (norm up to $100 \mu \mathrm{g}$ ) in the daily collection of urine collected in the dark. The morning urine sample was collected and studied under the Wood lamp. As seen in Figure 2, it was pink, which is highly pathognomonic for porphyria.

Treatment with hydroxychloroquine $200 \mathrm{mg}$ a day was implemented, and was reduced to $200 \mathrm{mg}$ twice a week after clinically evident improvement. After the gynecological consultation the patient could continue treatment with estradiol. The patient was advised to avoid alcohol consumption and excessive sun exposure. We also advised the patient to use wide-spectrum photoprotection in the form of creams with a UV filter and protective clothing.

After implementation of the treatment, skin lesions gradually disappeared, and no new ones appeared. Treatment with hydroxychloroquine was completed after 6 months. Unfortunately, as the patient has not shown up for a follow-up, we could not assess the ultimate treatment results.

\section{DISCUSSION}

We present a case of a mild form of PCT. Our patient was taking estrogens due to endometriosis. The skin lesions were created as a consequence of exposure to the sun.

Non-inflammatory blisters and later crusts are the main trigger that lead patients to seek professional help. Even if the patient has only a few lesions, yet has a typical past medical history, one should think about PCT in differential diagnosis.

An extremely common triggering and aggravating factor for PCT is estrogen therapy [12]. The exact mechanism has not been studied yet [13]. Despite this fact, estrogens are the main risk factor among women taking hormonal replacement therapy or oral contraception pills.

Diagnostics for PCT include examining the plasma porphyrin levels, porphyrins in the urine (mainly uroporphyrin and 7-carboxylated porphyrin), porphyrins in feces (mainly isocoproporphyrine), determination of excretion of porphyrin precursors (deltaaminolevulinic acid - ALA and porphobilinogen - PBG) - their elevated excretion is the basis for the diagnosis of the disease. Another useful measure is determination of the plasma porphyrin fluorescence gotowania do zabiegu zapłodnienia in vitro, po 3 iniekcjach gonadoliberyny. W wywiadzie stwierdzono leczenie dwukomorowej torbieli jajnika i zapalenie otrzewnej w 2000 roku, a 3 tygodnie po zapaleniu otrzewnej zabieg chirurgiczny z powodu endometriozy. Wykluczono zakażenie wirusem zapalenia wątroby typu C i B oraz HIV.

Ze względu na nasiloną podatność skóry rąk na uszkodzenia, nasilenie powstawania pęcherzy wskutek narażenia na promieniowanie $U V$, ciemnobrązowy mocz oraz typowy wynik badania LBT wysunięto podejrzenie PCT.

Podczas hospitalizacji wykonano badania w kierunku porfirii. Stwierdzono wzrost stężenia protoporfiryny $\mathrm{i}$ koproporfiryny do $270 \mu \mathrm{g} \mathrm{w}$ czasie 24 godzin (norma do $100 \mu \mathrm{g}$ ) w dobowej zbiórce moczu (pojemnik z moczem przechowywany w ciemnym miejscu). Pobrano próbkę pierwszego porannego moczu i zbadano w świetle lampy Wooda. Mocz miał różowe zabarwienie, co stanowi charakterystyczny objaw porfirii (ryc. 2).

Zastosowano leczenie hydroksychlorochiną $\mathrm{w}$ dawce $200 \mathrm{mg} /$ dobę, a następnie po osiągnięciu klinicznie istotnej poprawy dawkę zmniejszono do $200 \mathrm{mg}$ dwa razy $\mathrm{w}$ tygodniu. Po konsultacji ginekologicznej ustalono, że pacjentka mogła kontynuować leczenie estradiolem. Chorej zalecono unikanie spożywania alkoholu i nadmiernej ekspozycji na słońce. Poinformowano ją także o konieczności stosowania różnych metod ochrony przeciwsłonecznej, m.in. kremów z filtrem UV i odzieży ochronnej.

Po wdrożeniu leczenia stwierdzono stopniowe ustępowanie zmian skórnych oraz brak nowych wykwitów. Leczenie hydroksychlorochiną zakończyło się po 6 miesiącach. Ponieważ pacjentka nie zgłosiła się na wizytę kontrolną, nie można było ocenić końcowych efektów leczenia.

\section{OMÓWIENIE}

Przedstawiamy przypadek łagodnej postaci PCT u pacjentki leczonej estrogenami z powodu endometriozy. Zmiany skórne pojawiły się wskutek ekspozycji na słońce.

Powstawanie pęcherzy niezapalnych i późniejsze tworzenie się strupów stanowią główny czynnik skłaniający pacjentów do zgłaszania się do lekarza. Jeżeli u chorego widocznych jest zaledwie kilka zmian, ale wywiad lekarski jest typowy dla PCT, należy uwzględnić tę chorobę $\mathrm{w}$ diagnostyce różnicowej.

Bardzo częstym czynnikiem wyzwalającym i zaostrzającym w PCT jest terapia estrogenowa [12]. Mechanizm tej zależności nie został dokładnie zbadany [13], jednak estrogeny są głównym czynnikiem ryzyka u kobiet stosujących hormonalną terapię zastępczą lub doustne tabletki antykoncepcyjne.

Diagnostyka w kierunku PCT obejmuje oznaczenie stężenia porfiryn $\mathrm{w}$ osoczu, porfiryn $\mathrm{w}$ moczu (głównie uroporfiryny i porfiryny 7-karboksylowej), porfiryn 
spectrum, which has a highly specific range for PCT. An assumed diagnosis can be made by examination of urine under a Wood's lamp in the dark and after exposure to natural light. After several hours of exposure to natural light it changes color to red or brownish, due to excessive excretion of porphyrins.

Porphyria cutanea tarda treatment is based on drug discontinuation, phlebotomy and oral antimalarials [14]. Phlebotomy 400-500 ml every 2 weeks until serum ferritin falls to $20 \mathrm{ng} / \mathrm{ml}$ is as effective as low dose anti-malarial therapy (usually hydroxychloroquine $100 \mathrm{mg}$ twice a week or chloroquine $125 \mathrm{mg}$ twice a week) [15]. While treating with phlebotomies, special care should be taken not to induce anemia. Chloroquine works by accelerating the secretion of porphyrins and is thought to inhibit porphyrin synthesis [16]. Chloroquine and phlebotomy can be used simultaneously to induce faster remission.

However, the benefits of anti-malarial treatment outweigh the phlebotomy, due to higher compliance [17]. They lower the risk of transmission of infectious diseases, such as HCV. Approximately 6 months of therapy is usually needed for a good therapeutic outcome. According to the current guidelines our patients were treated with anti-malarial drugs. The treatment of PCT additionally consists of avoidance of triggering factors via spectral photoprotection, creams with a filter and protective clothing. Avoidance of sun exposure and alcohol consumption is highly recommended as well.

Moreover, we recommend considering systemic lupus erythematosus (SLE) in the differential diagnosis of skin lesions erupted after sun exposure. It is underlined that about $40-70 \%$ of patients with SLE suffer from exacerbation or worsening of the symptoms of the disease after exposure to UV [18]. Typical skin lesions for SLE include erythema on the face, most commonly butterfly-like, and erythema erythematosus and erythema-scar skin lesions, which may resemble the lesions typical for PCT [19]. However, Raynaud's symptom, reduction in complement factors, hypergammaglobulinemia and lymphadenopathy are more pathognomonic for SLE.

\section{CONCLUSIONS}

In contrast to PCT, SLE is one of the systemic connective tissue diseases, commonly referred to as the collagenoses, which are caused by directing the immune system against our own body. Most frequently, SLE affects not only skin, but also joints and kidneys. The disease may have a very diverse course - from mild forms, constituting the majority of cases, to severe, even life-threatening [20]. For those reasons SLE should be ruled out, when assessing the patient for porphyria. w kale (głównie izokoproporfiryny), a także wydalania prekursorów porfiryn (kwasu delta-aminolewulinowego - ALA, porfobilinogenu - PBG) (wzmożone wydalanie stanowi podstawę do rozpoznania choroby). Inną przydatną metodą jest analiza widma fluorescencji porfiryny w osoczu, które ma bardzo charakterystyczny zakres dla PCT. Wstępne rozpoznanie można zweryfikować, badając mocz w świetle lampy Wooda w ciemności oraz po wystawieniu na naturalne światło. Po kilku godzinach ekspozycji na naturalne światło mocz zmienia zabarwienie na czerwone lub brązowawe z powodu nadmiernej zawartości porfiryn.

Leczenie PCT opiera się na odstawieniu leków indukujących, zabiegach flebotomii i stosowaniu doustnych leków przeciwmalarycznych [14]. Flebotomia 400-500 ml co 2 tygodnie aż do zmniejszenia stężenia ferrytyny w surowicy do $20 \mathrm{ng} / \mathrm{ml}$ jest równie skuteczna jak terapia lekami przeciwmalarycznymi w małych dawkach (zazwyczaj hydroksychlorochiną w dawce $100 \mathrm{mg}$ dwa razy w tygodniu lub chlorochiną w dawce $125 \mathrm{mg}$ dwa razy w tygodniu) [15]. Przy zabiegach flebotomii należy zachować szczególną ostrożność, aby nie wywołać niedokrwistości. Mechanizm działania chlorochiny polega na przyspieszaniu wydzielania porfiryn. Uważa się, że lek hamuje syntezę porfiryn [16]. Leczenie chlorochiną i flebotomię można stosować jednocześnie w celu przyspieszenia remisji.

Leczenie przeciwmalaryczne jest dobrze przestrzegane przez pacjentów i w odróżnieniu od procedur zabiegowych nie niesie ryzyka infekcji np. HCV [17]. Zazwyczaj około 6 miesięcy leczenia powoduje poprawę kliniczną. Zgodnie z obowiązującymi wytycznymi nasi pacjenci byli leczeni lekami przeciwmalarycznymi. Terapia PCT obejmuje także unikanie czynników wyzwalających objawy, czyli stosowanie różnych metod ochrony przeciwsłonecznej, kremów z filtrem i odzieży ochronnej. Bezwzględnie zaleca się unikanie narażenia skóry na słońce i spożywania alkoholu.

W diagnostyce różnicowej zmian skórnych pojawiających się po ekspozycji na słońce należy uwzględnić toczeń rumieniowaty układowy (systemic lupus erythematosus - SLE). Warto podkreślić, że u około 40-70\% pacjentów z SLE obserwuje się zaostrzenie objawów choroby po ekspozycji na promieniowanie UV [18]. Zmiany skórne w przebiegu SLE to rumień skóry twarzy oraz wykwity o charakterze rumieniowym i rumieniowo-bliznowaciejącym, które mogą przypominać zmiany charakterystyczne dla PCT [19]. Jednak objaw Raynauda, obniżenie poziomu czynników dopełniacza, hipergammaglobulinemia i limfadenopatia są charakterystyczne dla SLE.

\section{WNIOSKI}

Przedstawiamy pacjentkę, u której czynnikiem indukującym chorobę było leczenie estrogenami endo- 


\section{CONFLICT OF INTEREST}

The authors declare no conflict of interest. metriozy oraz ekspozycja na działanie promieniowania UV. W opisanym przypadku wczesne rozpoznanie pozwoliło na uniknięcie powikłań choroby [20].

\section{KONFLIKT INTERESÓW}

Autorzy nie zgłaszają konfliktu interesów.

\section{References}

\section{Piśmiennictwo}

1. Frank J., Poblete-Gutiérrez P.: Porphyria cutanea tarda: when skin meets liver. Best Pract Res Clin Gastroenterol Hepatol 2010, 24, 735-745.

2. Méndez M., Rossetti M.V., Del C., Batlle A.M., Parera V.E.: The role of inherited and acquired factors in the development of porphyria cutanea tarda in the Argentinean population. J Am Acad Dermatol 2005, 52, 417-424.

3. Cruz M.J., Alves S., Baudrier T., Azevedo F.: Porphyria cutanea tarda induced by tamoxifen. Dermatol Online J 2010, 16, 2.

4. Jalil S., Grady J.J., Lee C., Anderson K.E.: Associations among behavior-related susceptibility factors in porphyria cutanea tarda. Clin Gastroenterol Hepatol 2010, 8, 297-302

5. Hift R.J.: Porphyria cutanea tarda, iron, inflammation and diabetes mellitus. Br J Dermatol 2011, 165, $453-454$.

6. Haendchen L., Jordão J.M., Haider O., Araújo F., Skare T.L.: Porphyria cutanea tarda and systemic lupus erythematosus. An Bras Dermatol 2011, 86, 173-175.

7. Reich A., Welz K., Gamian E.: Porphyria cutanea tarda - analysis of main causes, clinical symptoms and laboratory abnormalities. Adv Dermatol Allergol 2009, 26, 25-33.

8. Liu S.W., Lien M.H., Fenske N.A.: The effects of alcohol and drug abuse on the skin. Clin Dermatol 2010, 28, 391-399.

9. Siersema P.D., Rademakers L.H.P.M., Cleton M.L., ten Kate F.J.W., de Bruijn W.C., Marx J.J.M., et.al.: The difference in liver pathology between sporadic and familial forms of porphyria cutanea tarda: the role of iron. J Hepatol 1995, 23, $259-267$.

10. Sauer G.F., Funk D.D.: Iron overload in cutaneous porphyria. Arch Intern Med 1969, 124, 190-196.

11. Winchester J.F.: Management of iron overload in dialysis patients. Semin Nephrol 1986, 6 (4 Suppl), $22-26$.

12. Bulaj Z.J., Franklin M.R., Phillips J.D., Miller K.L., Bergonia H.A., Ajioka R.S., et al.: Transdermal estrogen replacement therapy in postmenopausal women previously treated for porphyria cutanea tarda. J Lab Clin Med 2000, 136, 482-488.

13. Cruz M.J., Alves S., Baudrier T., Azevedo F.: Porphyria cutanea tarda induced by tamoxifen. Dermatol Online J 2010, 16 , 977-978.

14. Lecha M.: Guidelines in classification, diagnosis, and treatment of the photodermatoses 7. Endogenous: The (cutaneous) porphyrias. Eur Porphyria Initiat (EPI). "http://www.turkderm.org.tr" www.turkderm.org.tr/turkdermData/Uploads/files/murphy_guideline_cutaneous_porphyria.pdf (access 29.05.2019 r.).

15. Singal A.K., Kormos-Hallberg C., Lee C., Sadagoparamanujam V.M., Grady J.J., Freeman D.H., et al.: Low-dose hydroxychloroquine is as effective as phlebotomy in treatment of patients with porphyria cutanea tarda. Clin Gastroenterol Hepatol 2012, 10, 1402-1409.

16. Scholnick P.L., Epstein J., Marver H.S.: The molecular basis of the action of chloroquine in porphyria cutanea tarda. J Invest Dermatol 1973, 61, 226-232.

17. Chou T.C., Su Y.S., Wu S.M., Wang C.C., Lee C.H.: Successful treatment of refractory blisters in porphyria cutanea tarda with topical pimecrolimus combined with oral hydroxychloroquine: an alternative to phlebotomy in patients with renal insufficiency and anemia. Eur J Dermatol 2012, 22, 567-568.

18. Bickers D.R.: Sun-induced disorders. Emerg Med Clin North Am 1985, 3, 659-676.

19. Khosravi-Hafshejani T., Ghoreishi M., Kariminia A., Kalia S., Avina-Zubieta A., Reynolds J., et al.: Prior sun exposure and skinspecific auto-antibodies are associated with skin disease in systemic lupus erythematosus. In: Poster Session, Lupus 2017, A99.3-A100.

20. Toll A., Campo-Pisa P., Gonzalez-Castro J., Campo-Voegeli A., Azón A., Iranzo P., et al.: Subacute cutaneous lupus erythematosus associated with cinnarizine and thiethylperazine therapy. Lupus 1998, 7, 364-366.

Received: 25.06 .2019

Accepted: 21.07 .2019

Otrzymano: $25.06 .2019 \mathrm{r}$

Zaakceptowano: 21.07 .2019 r.

\section{How to cite this article}

Nowak M.A., Mehrholz D., Barańska-Rybak W., Nowicki R.J.: Early diagnosis of porphyria cutanea tarda as a key to avoiding scarring - a mild form of the disease. Dermatol Rev/Przegl Dermatol 2019, 106, 515-521.

DOI: https://doi.org/10.5114/dr.2019.89999. 